\title{
Canadian hare-lynx dynamics and climate variation: need for further interdisciplinary work on the interface between ecology and climate
}

\author{
Nils Chr. Stenseth* \\ Centre for Ecological and Evolutionary Synthesis (CEES), University of Oslo, PO Box 1066 Blindern, 0316 Oslo, Norway
}

The regular population cycles in the abundance of Canadian hare and lynx is featured in nearly all biology textbooks (Stenseth 1995a). It is used by ecologists as a prime example of how interactions between predators (the lynx) and prey (the hare) might lead to regular population cycles (Krebs 2001, Begon et al. 2006). In addition, such interactions might also lead to non-cyclic population dynamic behaviour (e.g. May 1973). Although climate is known to affect the underlying nature of these population cycles (Stenseth et al. 1999), it is not fully understood to what extent climate contributes to the character of the dynamic hare-lynx population interaction. In fact, the extent of the climate influence on dynamic ecological systems has been passionately debated within the field of ecology for almost a century: Elton (1924) focused on intrinsic factors as the key determinants of the observed population dynamics of natural populations, while Andrewartha \& Birch (1954) argued the importance of extrinsic factors such as climate. Although the pioneers within this debate favoured an either/or categorical view, it is now generally agreed upon that both intrinsic densitydependent factors and extrinsic density-independent factors determine the observed population dynamics (e.g. Turchin 1995). The dynamics of the snowshoe hare Lepus americanus and the Canadian lynx Lynx canadensis is a prime example for assessing the relative importance of the two factors, with climate as the main extrinsic density-independent factor. This is the topic of the paper published by Zhang et al. (2007, this issue). They demonstrate that both intrinsic and extrinsic factors contribute significantly to the observed patterns, using the classic Hudson Bay data on hare and lynx.
The hare-lynx cycle is a very good case in point. Prior to Zhang et al.'s (2007) study, it was documented that the North Atlantic Oscillation (NAO) played a structuring role for the dynamics of the hare-lynx system across the entire Canadian subcontinent, both with respect to ecology (e.g. Stenseth et al. 1999) and population-genetic structuring (e.g. Rueness et al. 2003). In short, climate was seen as a forcing ecological factor which determines the population genetic structure (e.g. Stenseth et al. 2004a). Earlier studies also indicated that the nature of the snow might be the key physical determinant of the climate-ecology link (e.g. Stenseth et al. 2004b). Zhang et al. (2007) extend these studies by showing that another prominent climate pattern, the El Niño Southern Oscillation (ENSO), also plays a key role in the dynamics of the hare-lynx system. By so doing, they suggest that the structuring of the ecological dynamics might be more complicated than originally envisioned by Stenseth et al. (1999), who suggested that regional differences in climate driven by the NAO resulted in a geographic grouping of lynx population dynamics.

Large-scale climate phenomena such as the NAO and ENSO are potentially of great importance to ecologists (e.g. Stenseth et al. 2003). Such climate phenomena are essentially packages of weather (cf. Stenseth \& Mysterud 2005) having a much greater influence on ecosystems than single weather features: what influences living organisms is a combination of various weather components integrated over some window of time and space (the magnitude of which is not easy to assess). Therefore, empirical studies have demonstrated that indices of large scale climate modes are better predictors than individual weather parameters 
(e.g. Hallett et al. 2004, Stenseth \& Mysterud 2005), which have traditionally been favoured by ecologists.

As I see it, it remains a major interdisciplinary challenge to further understand why this is so. It is my hope that there will be more interdisciplinary work addressing such ecology-climate issues, that also involves the important input of statisticians. Zhang et al.'s (2007) study suggests that such interdisciplinary work could help to further our understanding of the ecological effects of climate change. In the future, it is conceivable that we may see dramatic changes in the hare-lynx cycle due to climate change. I suggest that studies of the hare-lynx cycle, such as that of Zhang et al. (2007), provide valuable insights into this field, just as the study of this cycle has played an instrumental role in the development of general ecological theory. An interdisciplinary journal such as Climate Research would certainly be an ideal forum for reporting such work that interfaces between climate and ecology.

Acknowledgements. I thank Stephen Dery and Jim Hurrell for stimulating discussions on snow and climate in Canada.

\section{LITERATURE CITED}

Andrewartha HG, Birch LC (1954) Distribution and abundance of animals. University of Chicago Press, Chicago, IL

Begon M, Townsend CR, Harper JL (2006) Ecology, 4th edn. Blackwell Publishing, Oxford

Elton CS (1924) Periodic fluctuations in numbers of animals: their causes and effects. Br J Exp Biol 2:119-163

Hallett TB, Coulson T, Pilkington JG, Clutton-Brock TH, Pemberton JM, Grenfell B (2004) Why large-scale climate indices seem to predict ecological processes better than local weather. Nature 430:71-75

Krebs CJ (2001) Ecology: the experimental analysis of distribution and abundance. Benjamin Cummings, New York

May RM (1973) Complexity and stability of model ecosystems. Princeton University Press, Princeton, NJ

Rueness EK, Stenseth NC, O'Donoghue M, Boutin S, Ellegren
H, Jakobsen KS (2003) Ecological and genetic spatial structuring in the Canadian lynx. Nature 425:69-72

Stenseth NC (1995a) Snowshoe hare populations: squeezed from below and above. Science 269:1061-1062

Stenseth NC (1995b) The long-term study of voles, mice and lemmings: homage to Robert Collett. Trends Ecol Evol 10:512

Stenseth NC, Mysterud A (2005) Weather packages: finding the right scale and composition of climate in ecology. J Anim Ecol 74:1195-1198

Stenseth NC, Chan KS, Tong H, Boonstra R, and 7 others (1999) Common dynamic structure of Canada lynx populations within three climatic regions. Science 285: 1071-1073

Stenseth NC, Ottersen G, Hurrell JW, Mysterud A, Lima M, Chan KS, Yoccoz NG, Ådlandsvik B (2003) Studying climate effects on ecology through the use of climate indices: the North Atlantic Oscillation, El Niño Southern Oscillation and beyond. Proc R Soc Lond B 270:2087-2096

Stenseth NC, Ehrich D, Rueness EK, Lingjærde OC and 6 others (2004a) The effect of climatic forcing on population synchrony and genetic structuring of the Canadian lynx. Proc Nat Acad Sci USA 101:6056-6061

Stenseth NC, Shabbar A, Chan KS, Boutin S and 5 others (2004b) Snow conditions may create an invisible barrier for lynx. Proc Nat Acad Sci USA 101:10632-10634

Tong H (1990) Non-linear time series. Clarendon Press, Oxford

Turchin P (1995) Population regulation: old arguments and a new synthesis. In: Cappuccino N, Price PW (eds) Population dynamics: new approaches and synthesis. Academic Press, New York

Zhang Z (2001) Relationship between El Niño/South Oscillation (ENSO) and population outbreaks of some lemmings and voles in Europe. Chin Sci Bull 46:1067-1074

Zhang Z, Li D (1999) A possible relationship between outbreaks of the oriental migratory locust (Locusta migratoria manilensis Meyen) in China and the El Niño episodes. Ecol Res 14:267-270

Zhang Z, Pech R, Davis S, Shi D, Wan X Zhong W (2003) Extrinsic and intrinsic factors determine the eruptive dynamics of Brandt's voles Microtus brandti in Inner Mongolia, China. Oikos 100:299-310

Zhang Z, Tao Y, Li Z (2007) Factors affecting hare-lynx dynamics in the classic time series of the Hudson Bay Company, Canada. Clim Res 34:83-89 